\title{
Challenges of access to water and sanitation for sustaining health: A case study from South 24 Parganas, West Bengal, India
}

\author{
Meena Sehgal \\ The Energy and Resources Institute (TERI), Darbari Seth Block \\ IHC Complex, Lodhi Road, New Delhi, 110 003, India \\ Sumit Kumar Gautam (Corresponding author) \\ The Energy and Resources Institute (TERI), $4^{\text {th }}$ Main, $2^{\text {nd }}$ Cross \\ Domlur $2^{\text {nd }}$ stage, Bangalore, 560071, India \\ Tel: 91-80-2535-6590Ｅ-mail: gautamsk2005@gmail.com
}

Priyanka Bajaj

The Energy and Resources Institute (TERI), Darbari Seth Block

IHC Complex, Lodhi Road, New Delhi, 110 003, India

57/34 Nehru Road, Dehra Dun, Uttarakhand, India

Mayukhmala Guha

Child in Need Institute (CINI), Village Daulatpur, P.O.-Pailan

Via- Joka, 24 Parganas (S) - 700104, India

Suneel Pandey

The Energy and Resources Institute (TERI), Darbari Seth Block

IHC Complex, Lodhi Road, New Delhi, 110 003, India

Received: January 10, 2014 Accepted: February 2, 2014

doi:10.5296/emsd.v6i1.11091

URL: https://doi.org/10.5296/emsd.v6i1.11091 


\section{Abstract}

The present study attempts to determine the access to clean water and sanitation essential for sustaining health. It attempts to identify socio-economic factors which influence access to clean water within the community. The absence of water-on- premises in a water abundant area of West Bengal, India showcases some of the challenges in progressing on Sustainable Development Goal-3.

Eight villages were included in the study and a total of 597 households were enrolled for the study from 8000 households in the villages. The study includes descriptive analysis of water access and sanitation parameters, and regression analysis of socio-economic determinants of exposure. The results reveal that nearly half of the respondents belonged to Above Poverty Line (APL) while $42.71 \%$ were under Below Poverty Line (BPL). Although majority of the household had access to an improved source of water for drinking, $77.89 \%$ of the households were using pond water for bathing, washing clothes, utensils and toilet and nearly $37 \%$ of households did not have any toilet facility. Regression analysis of use of pond water indicates that people living in mud huts (kutcha houses) and from religious minority groups were more likely to use ponds for washing utensils, clothes, bathing and defecated in open fields and use unimproved sources for drinking water.

The study asserts the need to develop community level preventive measures such as access to clean water for personal and domestic use and sanitation facilities to protect health.

Keywords: Clean water, Disease prevention, Sustaining health, Open defecation

\section{Introduction}

According to the Organization for Economic Co-operation and Development (OECD), financial expenditure on the water supply and sanitation has been $1.01 \%$ of the global GDP during 2000-2010 and this is expected to rise to 1.03\% during 2020-2030 (OECD, 2009). As per estimations, $54 \%$ of the people globally had access to piped water in their premises in 2010 as compared to $45 \%$ in 1990 (WHO and UNICEF, 2012). World-wide, a total of 2.3 billion people attained access to improved source of potable water during 1990-2012. With this, the target of halving the proportion of people without access to improved sources of water was achieved (WHO and UNICEF, 2014). It was also predicted that globally, 2.5 billion people would still be lacking access to improved source of water and around 784 million individuals would be short of access to safe drinking water by the year 2012 . Collectively, ten countries are the home for two-third of the global population without an improved source of drinking water. China had the maximum number of such people (119 million) followed by India (97 million) (WHO and UNICEF, 2012). Thus, there is a need for commitment to raise the financial expenditure both locally as well as globally.

India houses about $16 \%$ of the world's population but holds only $4 \%$ of global water resource $(\mathrm{NIH}, 2010)$. However, rapidly growing population coupled with scarcity of resources and impacts of climate change has resulted in serious challenges related to the sustainable management of the water resources including ensuring the adequate quantity and quality to meet various needs. 
According to Millennium Development Goals India Country Report (2014), India witnesses the significant improvement in drinking water indicator but the progress is relatively slow for indicators of sanitation practices. National Sample Survey (2012) reported that $88.5 \%$ rural household and 95\% urban households in India were getting drinking water from an improved source; out of this, $46.1 \%$ rural and $76.8 \%$ urban households had drinking facilities within their premises. Apart from dichotomy that exists in the sanitation and drinking water facilities in rural and urban India, inter-state disparity has also been noticed and widely acknowledged. For instance, the state of Himachal Pradesh reports the highest (94.4\%) proportion of households getting water within premises while this figure stands at $49 \%$ for the state of West Bengal (NSSO, 2012). This statistics is of immense relevance in the light of earlier analysis of global database from 193 countries which suggests that increasing the number of people having access to improved water is significantly associated with reduced under five mortality rate, odds of under-five mortality due to diarrhoea, infant mortality rate, and decreased odds of maternal mortality ratio (Cheng et al., 2012).

Further, there are strong evidences which demonstrate that open defecation has a strong positive correlation with stunting (Spears, 2013a, 2013b). A total of $82 \%$ of the people practicing open defecation belongs to developing countries. To address the issue of open defecation, India launched the Total Sanitation Campaign (TSC) in the year 1999 with an objective of improving the quality of life of rural people by impacting upon individual health and providing privacy and dignity to women. However, recent sanitation statistics from India reveals that $59.4 \%$ rural households and $8.8 \%$ urban households had no latrine facilities (Ministry of Statistics and Programme Implementation, 2014). Tripura et al. (2013) concluded that improved saniation (use of latrine; hand washing) and hygiene condition are instrumental in reducing the cases of intestinal helminthiasis in under-five children. Similarly, positive correlation was also reported between having no latrines in households and average incident rate (per 1000) of diarrhea, enteric fever and viral hepatitis in West Bengal (Nath, 2006). National level government programs such as Total Sanitation Campaign, have highlighted that six-year-olds who had been exposed to India's sanitation programme during their first year of life were more likely to recognize letters and simple numbers on learning tests than those who were not (Spears and Lambha, 2011).

Health indicators particularly nutrition status reported in national as well district level health surveys depicts that the population in our study area is vulnerable to water borne diseases due to reliability on unsafe water and poor sanitation practices at large and needs multi-sectoral interventions for improving health parameters. Three rounds of District Level Household Survey [DLHS] have been undertaken by the Ministry of Health and Family Welfare, Government of India, in the past conducted with periodicity of five years (Round-I in 1998-99, Round-II in 2002-04, Round-III in 2007-08, and DLHS-4 in 2011-12) with the main objective of providing reproductive- and child health-related database at district level in India. DLHS (2013) has reported that $28.2 \%, 37.4 \%$ and $37.4 \%$ of the under five children in West Bengal are wasted, stunted and underweight respectively. The anemia levels in West Bengal are also extremely high with $87.7 \%$ of the under five children and $79.2 \%$ of pregnant women respectively suffering from anemia (DLHS, 2013). In addition to drinking water, 


\section{Macrothink}

access to clean water to meet various domestic needs along with sanitary defecation options, are needed to sustain health for the masses. Thus, the present study determines the access to clean water and sanitation for sustaining health and to identify socio-economic factors which influence access to clean water within the community in the absence of water-on- premises in the water abundant rural communities of the state of West Bengal. The map of the study region is shown in Figure 1.

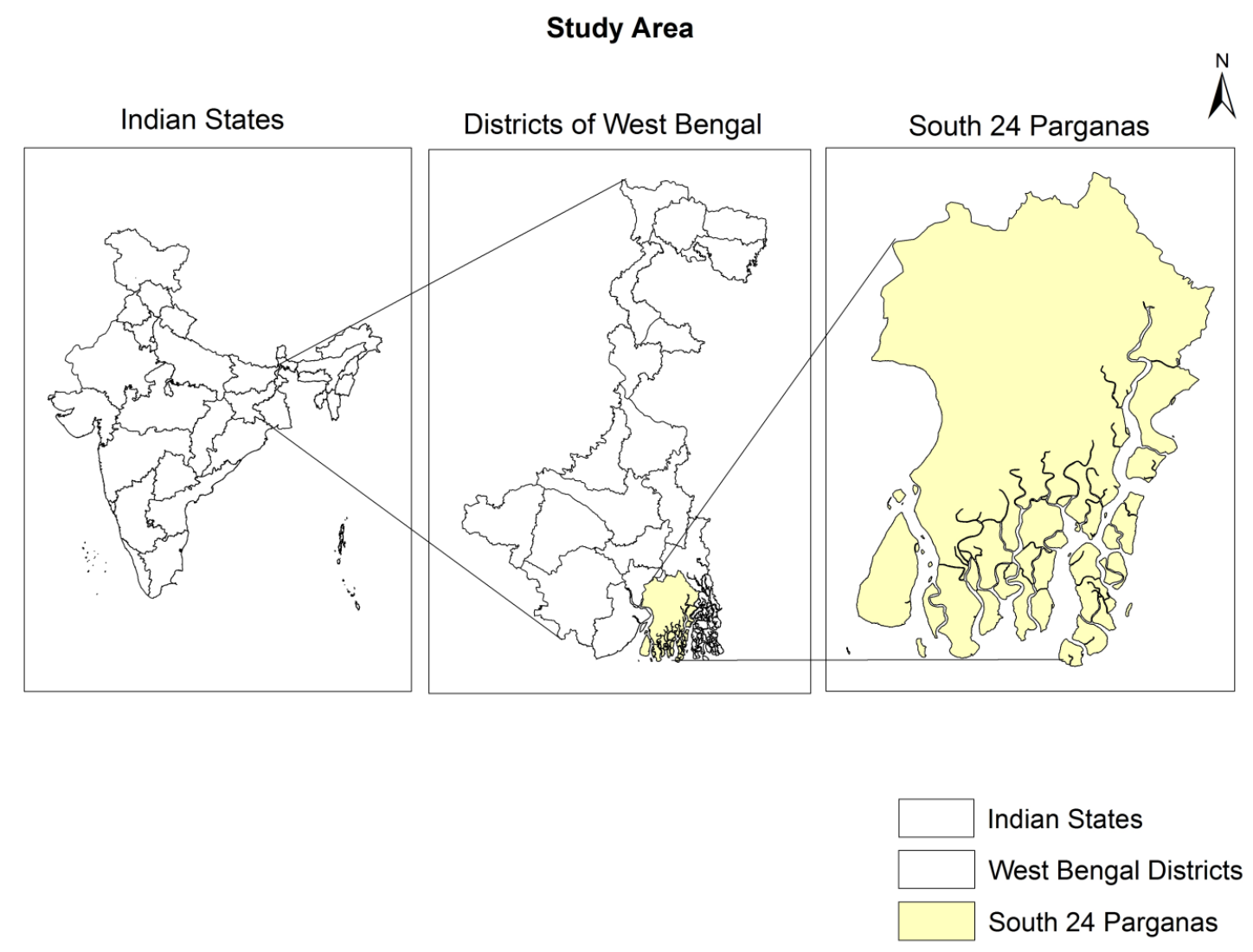

Figure 1. The map of the study region

\section{Methodology}

The study was conducted in eight villages in Bishnupur-I, and Bishnupur-II blocks (administrative units in a district) of coastal district of South 24 Parganas in the state of West Bengal. The trained Accredited Social Health Activists (ASHA workers) were engaged in identifying the various localities suitable to the study's objectives of interest within these villages. The health workers, after an extensive field study, prepared the social maps of the locality, which aided in selecting the households. Out of 8000 existing households, a total of 597 households were enrolled in this study. Systematic random sample of every 10th house in the locality was selected for the study. When the 10th household was not available for any reason, then the 11th household was approached for participation in the study. The questionnaire was administered in each of these households. The questionnaire created for data collection was translated in local language (Bangla), pilot tested and administered. Through the questionnaire survey, detailed information pertaining to socio-economic status, 
sanitation practices, availability and utilization of different water sources, and over-all awareness level on Water and Sanitation was sought. The collected information was synthesized and regression analysis was carried out. The used questionnaire is annexed to the manuscript [Annex 1].

\section{Results}

The baseline data collected from the surveys illustrates that the majority of the families $(83.42 \%)$ were headed by a male member. Three forth $(74.37 \%)$ of the population were of Hindu religion. Approximately one fourth of the families belonged to Islam religion and less than a percent $(0.34 \%)$ of the population practiced Christianity. Half of the population belonged to schedule caste, schedule tribes or other backward classes. Approximately $70 \%$ of the respondents and majority of the household heads had attended primary school.

Nearly half $(46.23 \%)$ of the respondents belonged to Above Poverty Line (APL) category, $42.71 \%$ of the respondents were Below Poverty Line (BPL) and $4.86 \%$ respondents had Antyodaya Ration Cards (food subsidy card given to poorest of the poor). Apart from this $6.20 \%$ respondents did not have any ration card issued to them. The majority of the respondents $(90.02 \%)$ possessed their own land (area less than one acre) while $5.08 \%$ of respondents did not have any land holding. More than half $(56.78 \%)$ of the respondents were staying in kutcha houses (wall and roof constructed with mud and straw). Only $22.45 \%$ of respondents had pucca (wall and/or roof constructed with bricks, cement and tiles) house. Respondents also reported of staying in huts (14.74\%) and a small percent (5.03\%) had no house. Nearly $60 \%$ of the respondents reported staying in a nuclear family and rest $21.94 \%$ and $21.78 \%$ lived in joint and extended families respectively. As high as $91.02 \%$ of the households $(91.02 \%)$ used electricity as a source of light and $8.17 \%$ used kerosene lamps. Wood (75\%), crop residue (30\%) and dunk cake (21\%) have been reported to be the most commonly used cooking fuel in the households while kerosene, biogas and charcoal were not the fuel of choice.

Majority (67\%) of the household has access to an improved source of drinking water; these households fetched water from the community/municipality tap or had a tap in their premises or used tube well for drinking. Table 1 illustrates the sources of water used for drinking and other domestic purposes by the households. Nearly half of the households had toilets without flush. Only $7.04 \%$ of the households reported to have toilets with flushes. However, one in four of the households practiced open defecation. The sanitation patterns followed in the household is detailed in Figure 2. 


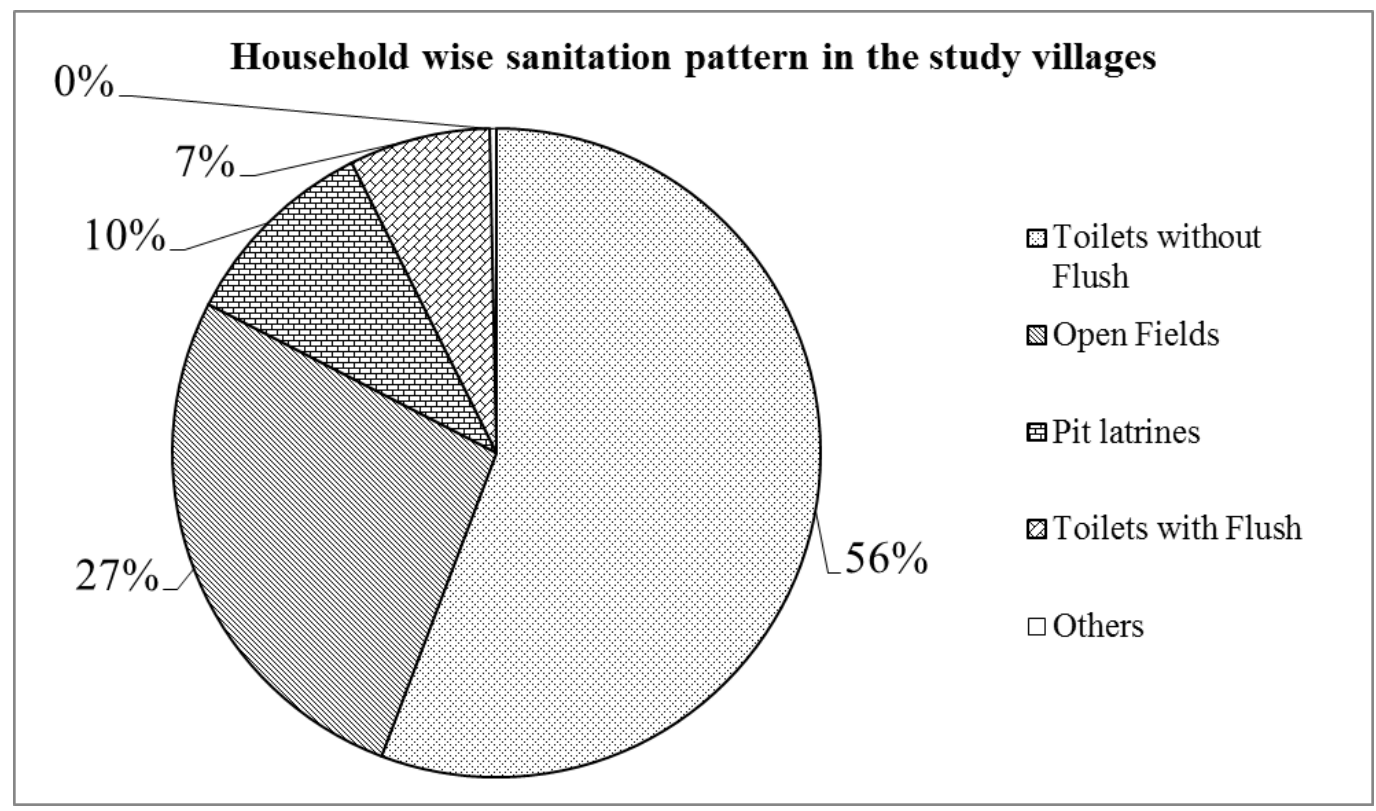

Figure 2. Household level sanitation pattern observed in the project area during the study

Approximately three fourth of the households were using natural pond water for bathing, washing clothes, utensils and toilets. The other sources of water used for domestic purposes included tube wells, taps and river water. A few households had access to piped water on their premises. Details of sources of domestic water have been enlisted in Table 1 .

Table 1. Sources of water used in the households for different purposes

\begin{tabular}{|l|l|l|l|l|l|}
\hline $\begin{array}{l}\text { Source of } \\
\text { water }\end{array}$ & $\begin{array}{l}\text { Drinking } \\
\%(\mathbf{n})\end{array}$ & $\begin{array}{l}\text { Bathing } \\
\boldsymbol{\%}(\mathbf{n})\end{array}$ & $\begin{array}{l}\text { Washing clothes } \\
\%(\mathbf{n})\end{array}$ & $\begin{array}{l}\text { Washing utensils } \\
\%(\mathbf{n})\end{array}$ & $\begin{array}{l}\text { Toilet } \\
\%(\mathbf{n})\end{array}$ \\
\hline Tube well & $17.42(104)$ & $6.37(38)$ & $6.20(37)$ & $5.70(34)$ & $5.86(35)$ \\
\hline Government/ Community Tap & $61.31(366)$ & $11.55(69)$ & $7.04(42)$ & $9.55(57)$ & $7.04(42)$ \\
\hline Tap in the Premises & $17.42(104)$ & $13.57(81)$ & $12.73(76)$ & $13.90(83)$ & $12.9(77)$ \\
\hline River & - & $0.17(1)$ & $0(0)$ & $0.67(4)$ & $0(0)$ \\
\hline Pond & $3(18)$ & $77.89(465)$ & $79.73(477)$ & $72.20(431)$ & $78.56(469)$ \\
\hline
\end{tabular}

Majority of the households were using unfiltered/processed pond water as the main source of water for most domestic purposes. However, it was observed that higher percent of Muslim households were dependent on pond water for domestic purposes as compared to the Hindu 
households. Almost three quarters of the APL card holding household were also using pond water for domestic purpose with even higher percentage among below poverty line households (Table 2).

Table 2. Sanitation and water usage for domestic purpose by religion and economic class of the households [APL - Above Poverty Line; BPL - Below Poverty Line]

\begin{tabular}{|c|c|c|c|c|c|c|c|c|c|c|c|}
\hline \multirow[t]{2}{*}{ Purpose } & \multicolumn{2}{|c|}{ Religion } & \multicolumn{4}{|c|}{ Ration Card Type } & \multicolumn{5}{|l|}{ Housing } \\
\hline & $\begin{array}{l}\text { Hindu } \\
\%(n)\end{array}$ & $\begin{array}{l}\text { Islam } \\
\%(\mathbf{n})\end{array}$ & $\begin{array}{l}\text { APL } \\
\%(\mathbf{n})\end{array}$ & $\begin{array}{l}\text { BPL } \\
\%(n)\end{array}$ & $\begin{array}{l}\text { Antyodyoy } \\
\%(n)\end{array}$ & $\begin{array}{l}\text { No Ration } \\
\text { Card \%(n) }\end{array}$ & $\begin{array}{l}\text { No house } \\
\%(\mathbf{n})\end{array}$ & $\begin{array}{l}\text { Hut } \\
\%(\mathbf{n})\end{array}$ & $\begin{array}{l}\text { Kutcha } \\
\%(\mathbf{n})\end{array}$ & $\begin{array}{l}\text { Pucca } \\
\%(n)\end{array}$ & $\begin{array}{l}\text { Mansion } \\
\%(n)\end{array}$ \\
\hline $\begin{array}{l}\text { Not drinking } \\
\text { improved water }\end{array}$ & $\begin{array}{l}96 \\
(428)\end{array}$ & $\begin{array}{l}90 \\
(136)\end{array}$ & $\begin{array}{l}92.7 \\
(256)\end{array}$ & $\begin{array}{l}92.7 \\
(255)\end{array}$ & $\begin{array}{l}89.66 \\
(29)\end{array}$ & $100(37)$ & $1(3.3)$ & $\begin{array}{l}9 \\
(10.23)\end{array}$ & $\begin{array}{l}22 \\
(6.49)\end{array}$ & $\begin{array}{l}1 \\
(0.75)\end{array}$ & 0 \\
\hline $\begin{array}{l}\text { Pond water } \\
\text { for Bathing }\end{array}$ & $\begin{array}{l}73.87 \\
(328) \\
\end{array}$ & $\begin{array}{l}89.40 \\
(135) \\
\end{array}$ & $\begin{array}{l}71.17 \\
(213) \\
\end{array}$ & $\begin{array}{l}80.78 \\
(206) \\
\end{array}$ & $\begin{array}{l}93.10 \\
(27) \\
\end{array}$ & $\begin{array}{l}51.35 \\
(19) \\
\end{array}$ & $\begin{array}{l}96 \\
(29) \\
\end{array}$ & $\begin{array}{l}87.50 \\
(77) \\
\end{array}$ & $\begin{array}{l}79.94 \\
(271) \\
\end{array}$ & $\begin{array}{l}62.69 \\
(84) \\
\end{array}$ & $\begin{array}{l}4 \\
(66.67) \\
\end{array}$ \\
\hline $\begin{array}{l}\text { Pond water for } \\
\text { Washing Clothes }\end{array}$ & $\begin{array}{l}76.58 \\
(340)\end{array}$ & $\begin{array}{l}88.74 \\
(134)\end{array}$ & $\begin{array}{l}77.54 \\
(412)\end{array}$ & $\begin{array}{l}83.14 \\
(212)\end{array}$ & $\begin{array}{l}93.10 \\
(27)\end{array}$ & $\begin{array}{l}62.16 \\
(23) \\
\end{array}$ & $\begin{array}{l}96.67 \\
(29) \\
\end{array}$ & $\begin{array}{l}85.23 \\
(75) \\
\end{array}$ & $\begin{array}{l}81.71 \\
(277) \\
\end{array}$ & $\begin{array}{r}68.66 \\
(92) \\
\end{array}$ & $\begin{array}{l}50 \\
(3) \\
\end{array}$ \\
\hline $\begin{array}{l}\text { Pond water for } \\
\text { Washing Utensils }\end{array}$ & $\begin{array}{l}67.12 \\
(298)\end{array}$ & $\begin{array}{l}88.08 \\
(133)\end{array}$ & $\begin{array}{l}67.03 \\
(185)\end{array}$ & $\begin{array}{l}79.61 \\
(203)\end{array}$ & $\begin{array}{l}72.41 \\
(21)\end{array}$ & $\begin{array}{l}59.46 \\
(22)\end{array}$ & $\begin{array}{l}90 \\
(27)\end{array}$ & $\begin{array}{l}75 \\
(66)\end{array}$ & $\begin{array}{l}75.22 \\
(255)\end{array}$ & $\begin{array}{l}58.96 \\
(79)\end{array}$ & $\begin{array}{l}66.67 \\
(4)\end{array}$ \\
\hline Toilet & $\begin{array}{l}76.07 \\
(337) \\
\end{array}$ & $\begin{array}{l}86.09 \\
(130) \\
\end{array}$ & $\begin{array}{l}77.90 \\
(215) \\
\end{array}$ & $\begin{array}{l}83.07 \\
(211) \\
\end{array}$ & $\begin{array}{l}83.76 \\
(24) \\
\end{array}$ & $\begin{array}{l}51.35 \\
(19) \\
\end{array}$ & & & & & \\
\hline Open Defecation & $\begin{array}{l}21 \\
(96)\end{array}$ & $\begin{array}{l}41.72 \\
(63)\end{array}$ & $\begin{array}{l}23.55 \\
(65)\end{array}$ & $\begin{array}{l}30.59 \\
(78)\end{array}$ & $\begin{array}{l}41.38 \\
(12)\end{array}$ & $\begin{array}{l}13.8 \\
(5)\end{array}$ & $70(21)$ & $\begin{array}{l}54.55 \\
(48)\end{array}$ & $\begin{array}{r}24.63 \\
(83) \\
\end{array}$ & $\begin{array}{l}5.97 \\
(8)\end{array}$ & 0 \\
\hline
\end{tabular}

Table 3 demonstrates the results of regression analysis of use of natural ponds for different purposes to identify significant social determinants of usage. Multivariate regression analyses showed use of pond for bathing by religious group (estimate of 0.8512 , p value 0.0064 , odds ratio 2.34); by type of housing (estimate -.7004 , p value <0.0001, odds ratio 0.496 ). Another popular use of pond water was for washing clothes significant differences were noted for type of housing (estimate $-0.5546, \mathrm{p}$ value 0.0012 , odds ratio 0.574 ); and by religious group (estimate $0.6564, \mathrm{p}$ value 0.0313 , odds ratio 1.928). Similarly use of pond for washing utensils/dishes showed significant association for type of housing, estimate $-0.333, \mathrm{p}$ value 0.0262 , odds ratio 0.717); and for washing utensils/dishes by religious group (estimate 1.0704, $\mathrm{p}$ value 0.0003 , odds ratio 2.917 ). For other multivariate regression outputs reader is advised to refer to Table 3.

It was observed that the use of pond water for washing utensils, clothing and bathing was significantly associated with economic status (represented by type of housing), and religion. People living in mud huts/ kutcha houses and belonging to minority population (Muslims) were more likely to use natural pond for washing utensils, clothes, bathing, and defecate in the open field and less likely to have access to improved sources of water after adjusting for caste. 
Table 3. Regression analysis of socio-economic indicators on use of water sources for personal use and sanitation [APL - Above Poverty Line; BPL - Below Poverty Line]

\begin{tabular}{|c|c|c|c|c|c|}
\hline Variable & $\begin{array}{l}\text { Model 1: } \\
\text { Use of pond } \\
\text { for bathing } \\
\text { Estimate } \\
\text { (p value) } \\
\text { Odds ratio } \\
95 \% \text { CI }\end{array}$ & $\begin{array}{l}\text { Model 2: } \\
\text { Use of pond for } \\
\text { washing clothes } \\
\text { Estimate } \\
\text { (p value) } \\
\text { Odds ratio } \\
95 \% \text { CI }\end{array}$ & $\begin{array}{l}\text { Model } 3 \text { : } \\
\text { Use of pond for } \\
\text { washing utensils } \\
\text { Estimate } \\
\text { (p value) } \\
\text { Odds ratio } \\
95 \% \mathrm{CI}\end{array}$ & $\begin{array}{l}\text { Model } 4 \text { : } \\
\text { Defecation in the } \\
\text { open field } \\
\text { Estimate } \\
\text { (p value) } \\
\text { Odds ratio } \\
95 \% \mathrm{CI}\end{array}$ & $\begin{array}{l}\text { Model } 5 \text { : } \\
\text { Not Drinking from } \\
\text { improved sources } \\
\text { Estimate } \\
\text { (p value) } \\
\text { Odds ratio } \\
95 \% \text { CI }\end{array}$ \\
\hline $\begin{array}{l}1=\text { Yes } \\
2=\text { No }\end{array}$ & $\begin{array}{l}416 \\
111\end{array}$ & $\begin{array}{l}423 \\
104\end{array}$ & $\begin{array}{l}387 \\
140\end{array}$ & $\begin{array}{l}140 \\
386\end{array}$ & $\begin{array}{l}28 \\
499\end{array}$ \\
\hline $\mathrm{R}$ square & 0.05 & 0.06 & 0.06 & 0.16 & 0.095 \\
\hline$P$ value & $<.0001$ & .0003 & $<.0001$ & $<.0001$ & 0.0016 \\
\hline $\begin{array}{l}\text { Ration card: } \\
\text { 1-BPL } \\
\text { 2-APL }\end{array}$ & $\begin{array}{l}-0.0696 \\
(0.7625) \\
0.933 \\
(0.594,1.465)\end{array}$ & $\begin{array}{l}0.1219 \\
(0.6015) \\
1.130 \\
(0.715,1.785)\end{array}$ & $\begin{array}{l}0.4807^{*} \\
(0.0240) \\
1.617 \\
(1.065,2.455)\end{array}$ & $\begin{array}{l}0.0336 \\
(0.8785) \\
1.034 \\
(0.672,1.592)\end{array}$ & $\begin{array}{l}-0.7419 \\
(0.0757) \\
0.476 \\
(0.210,1.080)\end{array}$ \\
\hline $\begin{array}{l}\text { Religion: } \\
\text { 1-Hindu } \\
\text { 2-Islam }\end{array}$ & $\begin{array}{l}0.8512 * \\
(0.0064) \\
2.342 \\
(1.27,4.321)\end{array}$ & $\begin{array}{l}0.6564 * \\
(0.0313) \\
1.928 \\
(1.061,3.504)\end{array}$ & $\begin{array}{l}1.0704 * \\
(0.0003) \\
2.917 \\
(1.64,5.174)\end{array}$ & $\begin{array}{l}0.7609 * \\
(0.0012) \\
2.140 \\
(1.349,3.394)\end{array}$ & $\begin{array}{l}-0.7419^{*} \\
(0.0757) \\
2.85 \\
(1.27,6.38)\end{array}$ \\
\hline $\begin{array}{l}\text { Caste: } \\
\text { General } \\
\text { SC/ ST/OBC }\end{array}$ & $\begin{array}{l}-0.3486 \\
(0.1173) \\
0.706 \\
(0.456,1.092)\end{array}$ & $\begin{array}{l}-0.1103 \\
(0.6243) \\
0.896 \\
(0.576,1.393)\end{array}$ & $\begin{array}{l}-0.3286 \\
(0.1107) \\
0.720 \\
(0.481,1.078)\end{array}$ & $\begin{array}{l}-0.0841 \\
(0.7004) \\
0.919 \\
(0.599,1.411)\end{array}$ & $\begin{array}{l}-0.7038 \\
(0.0960) \\
0.495 \\
(0.216,1.133)\end{array}$ \\
\hline $\begin{array}{l}\text { Housing: } \\
\text { 0- no house } \\
\text { 1- hut } \\
\text { 2-kutcha } \\
\text { 3-pucca } \\
\text { 4-mansion }\end{array}$ & $\begin{array}{l}-0.7004 * \\
(<.0001) \\
0.496 \\
(0.354,0.697)\end{array}$ & $\begin{array}{l}-0.5546^{*} \\
(0.0012) \\
0.574 \\
(0.411,0.803)\end{array}$ & $\begin{array}{l}-0.333^{*} \\
(0.0262) \\
0.717 \\
(0.534,0.961)\end{array}$ & $\begin{array}{l}-1.2139 *(<.0001) \\
0.297 \\
(0.215,0.410)\end{array}$ & $\begin{array}{l}-0.4822 \\
(0.0566) \\
0.617 \\
(0.376,1.014)\end{array}$ \\
\hline
\end{tabular}

* significant at $p$ value $<0.05$.

\section{Discussion}

Analysis of the data highlights that the basic need of water for domestic purposes including drinking has not been adequately met in the study villages of West Bengal. The occurrence and spread of several tropical diseases particularly those caused by soil transmitted intestinal helminths (STHs) are inextricably associated to water, sanitation facilities and hygiene practices or the lack thereof. STH infections are transmitted by eggs present in human faeces which in turn contaminate the soil and water in areas where sanitation is poor. World Health Organization (WHO, 2001) passed a resolution aimed at the "deworming" of 75 percent of all at-risk school-age through distribution of the medications albendazole or mebendazole to 
control Soil-Transmitted Helminths (STH). The program has been able to achieve some success in reducing the severity of worm infections in some areas. This is an important progress, as infection with STH can lead to anaemia, vitamin A deficiency, stunting, malnutrition, impaired development, and intestinal obstruction (Donald, 2011). Further, report on Status of Water Quality in India (2011) states that total coliform and fecal coliform exceed the set maximum permissible limit for the ponds of West Bengal thereby making the pond water unfit for drinking or domestic purposes. The Natonal Family health Survey [NFHS] is a large-scale, multi-round survey conducted in a representative sample of households throughout India. It is undertaken every six years. Four rounds of the survey have been conducted since the first survey in 1992-93.

In the study population, $96 \%$ of the households were reported to have been using an improved source of water for drinking; these rates are similar to those reported in NFHS-4 (2015-16) which presented 98\% for South 24 Parganas, West Bengal. More than three-fourth (79.73\%) of the rural households use pond water for domestic purposes, putting a large section of community at risk of preventable diseases which are waterborne, water-based, water-related, and water-washed such as cholera, typhoid etc. The access to cleaner water for domestic use is determined by economic status and religion in our study area showcasing inequity in access to available resources.

Further, in our study area, nearly $37 \%$ of households did not have any toilet facility which is also comparable to rates reported in NFHS-3 data (40\%) for West Bengal and DLHS-4 data (42.3\%) for rural West Bengal. Similar evidence has been reported in other studies across the country. Prasad (2014) reported that one third of the households do not have separate toilets with flush and one fourth of the population practice open defecation.

Improved water, sanitation and education efforts aimed at prevention through hand washing and food preparation are critical to reducing spread of the diseases including diarrhea, intestinal helminthic disease, stunting and infant mortality. Recognizing these linkages, Government of India launched the National Rural Drinking Water Quality Monitoring and Surveillance Programme in 2006. The programme focuses on the monitoring and surveillance of all drinking water sources, decentralization of water quality monitoring, generation of awareness and building capacity of village institutions. Some of the challenges faced by the programme are limited trained manpower, infrastructure, data sharing and analysis (Srikanth, 2008).

According to Pacific Institute Research Report (Gleick, 2002) as many as 76 million would die across the globe, between 2000 and 2020 because of water borne diseases like cholera, water wash illnesses such as tick and lice, water based like schistosmaiasis or water related diseases like malaria. The failure to meet basic human needs for water affect the poor population directly and indirectly as the poor suffer in terms of sickness, lost education, employment and a massive number of early deaths (Gleick, 2002).

To address inadequate access to clean water for domestic use, and to reduce inequity in access, there is an urgent need for intervention and development of water smart villages. These could include a) Building and promoting of simple and safe local technologies/ 


\section{Macrothink}

mechanisms such as installation of community based pond water filtration system, water quality testing kits, water kiosks for providing clean water b) Larger network of water testing laboratories and lavatories in the community could bring substantial improvements c) Establishing and maintaining a village based waste water disposal system d) Further enhancements could be accrued through use of smart IT applications such as Instant Messaging to improve information flow and timely technical support for non-functioning technologies, or delivery of anti-helminthic drug supply to vulnerable communities. In the long term, tracking and indexing villages which provide clean water to meet the wide range of human needs including drinking, washing, bathing, and rinsing, increasing awareness among panchayat members to act as demand drivers for improving clean water access, quality maintenance and empowering of the local administrative units to identify need based approach to address the local challenges of domestic water and sanitation.

\section{Conclusion and Way Forward}

The data from the study, field observations and review of literature for nutrition and health statistics of the study area clearly warrants for investing in improving access to clean water for personal and domestic purposes and in sanitation facilities (see Figure 1) to sustain health and build the resilience of the community to associated vulnerability.
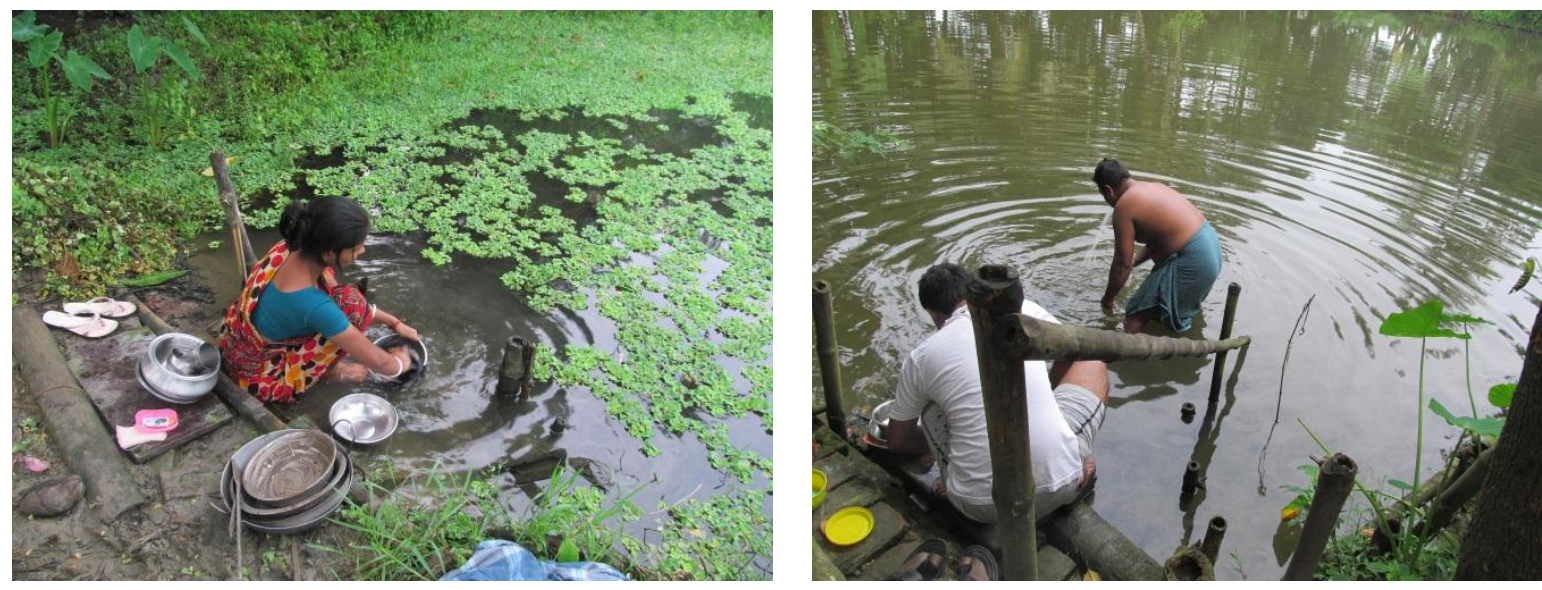

Figure 1. Domestic and personal use of untreated pond water in the study region

Low rate of in-premises source of drinking water, limited duration of water supply from community level tap (stand-post), abundance of shallow natural ponds, accompanied with widely prevalent practice of open defecation and subsequent dependence on other sources of water for domestic use indeed increases the risks of preventable diseases. Furthermore, an association of socio economic factors with access to clean water and availability of laterines within this water abundant community of West Bengal was observed; showcasing that water availability is not merely the amalgamation of factors such as infrastructure, availability and accessibility but is significantly associated with equity within the community.

Our study highlights some of the gaps in preventive and protective measures which are fundamental for protection of human health at large along with the treatment and curative approach of the health care system. Prevention partners harnessed from the corporates, the IT, 
the government, the academia and the community would bring about rich dividends. Future work may involve understanding the challenges to using municipality water for purposes other than drinking, determining quality of municipality water supply and at point of use, prevalence of disease potentially associated with poor quality of water for domestic purposes.

\section{Acknowledgement}

The authors sincerely thank Ministry of Health and Family Welfare (MOHFW), Government of India for providing financial assistance in conducting this survey under the collaborative research project to assess adverse health outcomes of exposure to household level air pollutants in rural community. The authors are also thankful to Dr Aditi Roychowdhury, Division of Women and Child Health and Development (DWCHD), Child in Need Institute (CINI) for reviewing the paper, health workers at CINI and villagers of Bishnupur I and II blocks for their cooperation in participating in the survey. Finally, we sincerely acknowledge the anonymous reviewers for their valuable time.

\section{References}

Cheng, J. J., Schuster-Wallace, C. J., Watt, S., Newbold, B. K., \& Mente, A. (2012). An ecological quantification of the relationships between water, sanitation and infant, child, and maternal mortality. Environmental Health. 11, 4. https://doi.org/10.1186/1476-069X-11-4

District Level Household and Facility Survey (DLHFS). (2012-2013). State Fact Sheet-West Bengal. Ministry of Health and Family Welfare, Government of India, New Delhi.

Donald, B. (2011). New Reasons Why School-Based Deworming is Smart Developing Policy. [www.worldbank.org., Accessed on December 02,2014.]

Gleick, P. H. (2002). Dirty Water: Estimated Deaths from Water-Related Diseases 2000-2020. Pacific Institute for Studies in Development. Environment and Security. Oakland.

Millennium Development Goals India Country Report., (2014). Social Statistics Division, Ministry of Statistics and Programme Implementation. Government of India. New Delhi, India.

Nath, K. (2006). Study on Disease Burden Due to Inadequate Water and Sanitation Facilities in India. Kolkata. Sulabh International Academy of Environmental Sanitation. India. [www.indiasanitationportal.org, Accessed on March 28, 2015].

National Family Health Survey (NFHS) 3. (2005-2006). Health and Living Condition in Eight Indian Cities -NFHS-3. Ministry of Health and Family Welfare, Government of India, New Delhi.

National Sample Survey Office (NSSO). (2012). Ministry of Statistics and Programme Implementation. Government of India, New Delhi.

OECD. (2009). Strategic financial planning for water supply and sanitation. [www.oecd.org/env/eap, Accessed on March 18, 2015]

Prasad, R. (2014). New approach needed to curb open defecation? The Hindu. 
[www.thehindu.com, Accessed on 17 August, 2014]

Spears, D. (2013a). The nutritional value of toilets, "How much international variation in child height can sanitation explain? Rice [www.riceinstitute.org, Accessed on January 7, 2015]

Spears, D. (2013b). The Long and Short of Open Defecation, The Hindu. 14 March 2013.

Spears, D., \& Lambha, S. (2011). Effects of Early-Life Exposure to Sanitation on Childhood Cognitive Skills: Evidence from India's Total Sanitation Campaign. [http://elibrary.worldbank.org, Accessed on April 30 ${ }^{\text {th }}$ 2015]

Srikanth, R. (2009). Challenges of sustainable water quality management in rural India. Current Science. 97, 317-325.

Status of Water Quality in India. (2011). Ministry of Environment and Forests, Government of India, Central Pollution Control Board, New Delhi.

Tripura, A., Reang, T., Tripura, K., \& Roy, A. (2013). A study of knowledge and practice on intestinal helminthiasis among rural tribal mothers of under five children in Mohanpur block, west district of Tripura: a north eastern state of India. Journal of Evolution of Medical and Dental Sciences. 2, 9081-9087. https://doi.org/10.14260/jemds/1575

Water Resources of India. (2010). National Institute of Hydrology (NIH), Roorkee, Uttarakhand. India.

WHO and UNICEF. (2012). Progress on drinking water and Sanitation 2012 update. [www.unicef.org/media/files/JMPreport2012.pdf, Accessed on April 28, 2015]

WHO and UNICEF. (2014). Progress on drinking water and Sanitation 2014 update.

\section{Annex 1: The questionnaire used in the study}

1. Number of eligible women (planning pregnancy/ currently pregnant ) in the $\mathrm{HH}$ :

Does she smoke beedi/cigarettes regularly?

Level of education (of the women being interviewed):
(1) No formal schooling
(2) Primary school
(3) Secondary or higher school

$\begin{array}{ll}\text { (4) Graduation } \square & \text { (5) No response }\end{array}$

2. Level of education (of the head of the $H H$ ):

(1) No formal schooling $\square \quad$ (2) Primary school $\square \quad$ (3) Secondary or higher school

(4)

Graduation $\square$ (5) No response

3. Which colour (category) of ration card does your family have?
(1) Above Poverty Line
(2) Below Poverty Line
(3) Below Poverty Line (Antyodaya Anna

Yojana) $\square$ (4) No response $\square$

4. What is your occupation?

(1) Household work

(2) Agriculture

(3) Labour

(4) Service

(5) Business

Others $\square$ (7) No response $\square$ (8) Any others, please specify 


\section{Macrothink}

Environmental Management and Sustainable Development

ISSN 2164-7682 2017, Vol. 6, No. 1

5. What is the occupation of the head of the household?
(1) Agriculture $\square$
(2) Labour
(3) Business
(4) Service
(5) Household work

(6)

Others $\square$ (7) No response $\square$ (8) Any others, please specify

\section{Housing characteristics}

6. Type of house (Observation by the interviewer)
(1) Pucca
(2) Semi- pucca
(3) Kutcha
(4) Others
(specify)

7. Total number of rooms:

8. How many meals do you cook in a day?
(1) One
(2) Two
(3) Three

\section{Energy Sources}

What is the primary energy for lighting
1. Kerosene
2. Solar Power
3. Electricity

9. Type of fuel used for cooking and / or water heating (tick mark in the appropriate column)

\begin{tabular}{|l|l|l|l|}
\hline S.No. & Type of fuel & Primary fuel & Secondary fuel \\
\hline 1. & Wood & & \\
\hline 2. & Twigs/branches/crop residues & & \\
\hline 3. & Dung cake & & \\
\hline 4. & Kerosene & & \\
\hline 5. & LPG & & \\
\hline 6. & Biogas (gobar) & & \\
\hline 7. & Charcoal & & \\
\hline 8. & Coal/coke/lignite & & \\
\hline 9. & Any others & & \\
\hline
\end{tabular}

Sanitation and Washing facilities

What are you currently using for the following

\begin{tabular}{|l|l|l|l|l|l|}
\hline & Hand pump & Municipality tap & Household level tap & River water & Pond \\
\hline bathing & & & & & \\
\hline washing clothes & & & & & \\
\hline washing dishes & & & & & \\
\hline toilet & & & & & \\
\hline
\end{tabular}




\section{Health related}

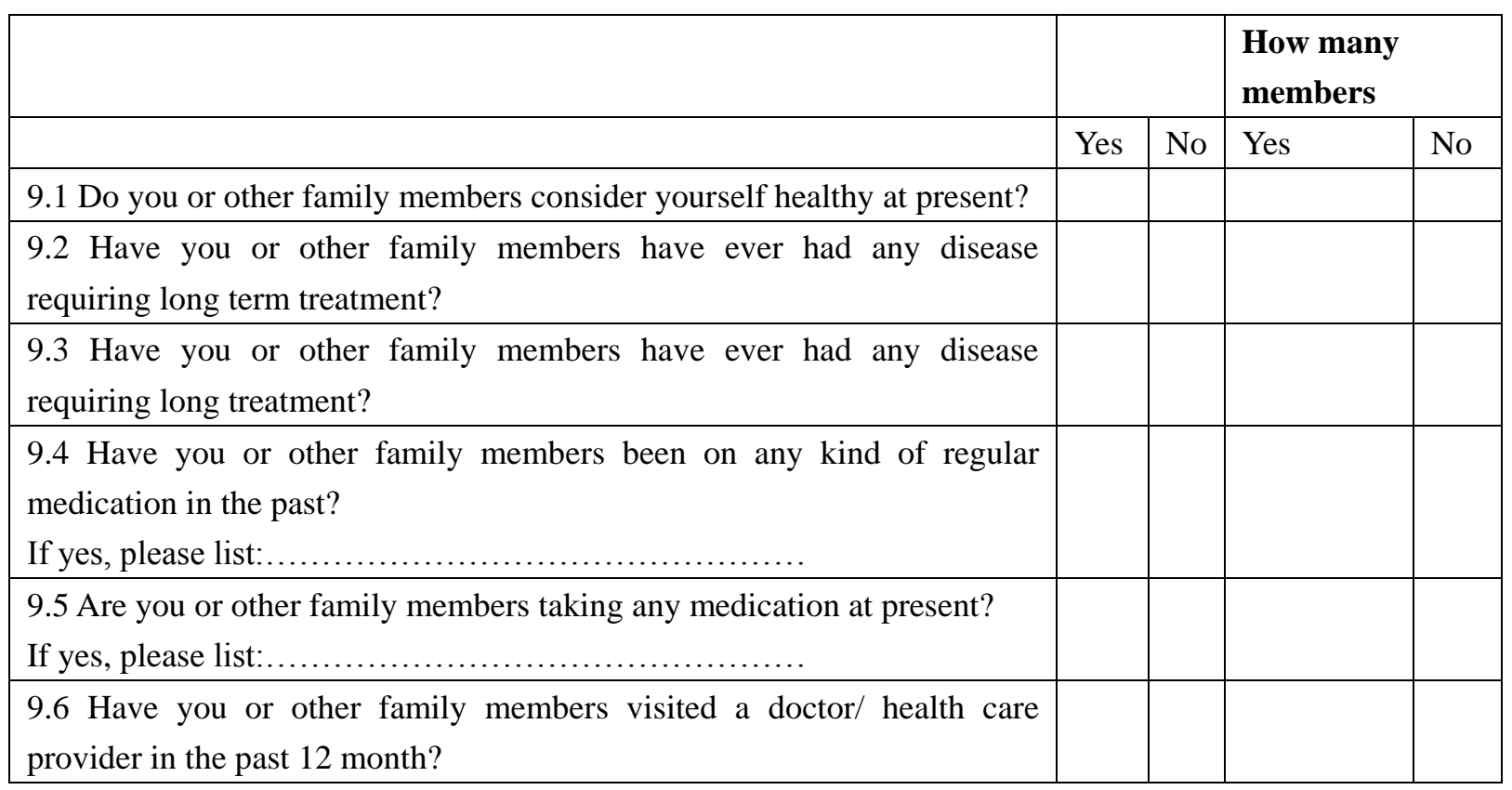

Thank you for your participation!

\section{Copyright Disclaimer}

Copyright for this article is retained by the author(s), with first publication rights granted to the journal.

This is an open-access article distributed under the terms and conditions of the Creative Commons Attribution license (http://creativecommons.org/licenses/by/3.0/). 